\title{
Implementasi Sistem Informasi Inventaris Barang pada PT.PLN (Persero) Palembang
}

\author{
Nurul Huda ${ }^{[1]^{*}}$, Rahayu Amalia ${ }^{[2]}$ \\ Fakultas Ilmu Komputer, Universitas Bina Darma ${ }^{[1],[2]}$ \\ Jalan A. Yani no.3 Palembang, Indonesia \\ nurul_huda@binadarma.ac.id ${ }^{[1]}$,rahayu_amalia@binadarma.ac.id ${ }^{[2]}$
}

\begin{abstract}
PT. Perusahaan Listrik Negara (Persero) WS2JB (South Sumatra, Jambi and Bengkulu Regions) Palembang rayon rivai branch is one of the branches of PT. PLN located in South Sumatra. At this time in processing data inventory still often experiences many obstacles such as frequent difficulties in presenting inventory data data reports that cause this inventory report to be inefficient in addition to the data processing is still done manually, so that in making reports often too late and also often occurs duplication. The method used in this study uses the waterfall method which has several stages, namely: Analysis, Design, Coding and Testing. This research will produce an inventory information system at PT. PLN Palembang branch rayon rivai. The result of this information system is that the system will present a more regular inventory data report in accordance with their respective divisions.

Keywords: Information Systems, Inventory, waterfalls
\end{abstract}

Abstrak--- PT. Perusahaan Listrik Negara (persero) WS2JB (Wilayah Sumatera Selatan, Jambi dan Bengkulu) cabang Palembang rayon rivai merupakan salah satu cabang PT. PLN yang berlokasi di Sumatera Selatan. Pada saat ini di dalam pengolahan data inventaris masih sering mengalami banyak kendala seperti sering terjadi kesulitan dalam penyajian laporan data barang inventaris yang menyebabkan laporan inventaris ini menjadi tidak efisien disamping itu pengolahan datanya masih dilakukan secara manual, sehingga dalam pembuatan laporannya sering terlambat dan juga sering terjadi duplikasi. Adapun metode yang digunakan dalam penelitian ini menggunakan metode waterfall yang memiliki beberapa tahapan yaitu: Analisis, Desain, Pengodean dan Pengujian. Penelitian ini akan menghasilkan suatu sistem informasi inventaris pada PT. PLN cabang Palembang rayon rivai. Adapun hasil dari sistem informasi ini yaitu sistem akan menyajikan laporan data barang invetaris yang lebih teratur sesuai dengan divisi nya masingmasing.

Kata Kunci : Sistem Informasi, Inventaris, waterfall

\section{PENDAHULUAN}

Dengan selalu berkembangnya teknologi informasi dari tahun ketahun menjadi tantangan berat bagi pengguna teknologi informasi. Hal tersebut mendorong setiap sektor organisasi baik formal maupun informal atau lembagalembaga lainnya untuk dapat memanfaatkannya sebagai penunjang kegiatan kerja sehingga dapat menghasilkan informasi yang cepat, tepat dan akurat. Untuk mewujudkan hal tersebut, maka dibutuhkan sumber daya pendukung lain seperti perangkat lunak yang dapat diandalkan kemampuannya. Selain itu sumber daya manusia juga harus menguasai kemampuan teknologi informasi itu sendiri.

PT. PLN (Persero) sebagai perusahaan BUMN dan penyedia sistem ketenaga listrikan nasional memiliki fungsi oleh pemerintah dalam menyediakan tenaga listrik ke seluruh Indonesia. PLN sebagai agen pembangunan juga mempunyai tugas merintis kegiatan-kegiatan usaha kelistrikan untuk meningkatkan kesejahteraan masyarakat secara adil dan makmur serta mendorong peningkatan ekonomi [1].

Laporan data barang - barang inventaris merupakan salah satu aspek penting dalam suatu organisasi, perusahaan maupun instansi pemerintah. Dari laporan inilah dapat diketahui informasi mengenai ada atau tidak adanya barang inventaris di suatu divisi atau bagian serta bagaimana kondisi barang inventaris tersebut.

Adapun permasalahan yang didapat selama melakukan penelitian diantaranya yaitu didalam proses penginputan dan pelaporan barang inventaris masih membutuhkan waktu yang lama dan juga sering sekali terjadi kesalahan-kesalahan maupun duplikasi data dikarenakan dalam pemrosesan data dan backup data inventaris barang baik barang habis pakai dan barang tidak habis pakai masih dilakukan dengan cara dicatat dan diinputkan menggunakan microsoft excel.

Berdasarkan penelitian yang dilakukan oleh Rakhel dkk, tahun 2016 dengan judul "Perancangan Sistem Informasi Inventaris berbasis mobile (Studi Kasus: STMIK Provisi Semarang)" menyatakan bahwa dengan adanya sistem informasi inventaris berbasis web mobile membuat proses pengelolaan data inventaris secara keseluruhan dapat dilakukan dengan dengan baik dan teratur [2]. Sedangkan berdasarkan Nono Sudarsono dan sukardi di tahun 2015, dengan judul "Sistem Informasi Inventory Berbasis Web di PT. Aututech Indonesia", mengatakan bahwa dengan dibangunnya sistem informasi inventory berbasis web ini dapat memberikan kemudahan bagi semua Departemen untuk melakukan pengecekan stok barang yang ada [3]. Sedangkan pada Sistem informasi pengelolaan data barang inventaris di PT. PLN (persero) di rayon rivai WS2JB area palembang ini diharapkan dapat memberikan laporan data barang inventaris dengan lebih efektif dan efisien karena setiap Divisi dapat melakukan pengecekan stok barang yang ada sehingga tidak terjadi lagi duplikasi data dalam laporannya. Adapun tujuan dari penelitian ini adalah untuk mengimplementasikan perancangan sistem informasi inventaris dalam penyajian 
laporan data barang - barang inventaris di PT. PLN (persero) di rayon rivai WS2JB palembang agar menjadi lebih baik, efektif, efisien dan lebih terkontrol.

\section{TINJAUAN PUSTAKA}

\section{A. Inventaris}

"Inventaris adalah item atau material yang dipakai oleh suatu organisasi atau perusahaan untuk menjalankan bisnisnya. Jika perusahaan tersebut memproduksi suatu barang atau jasa maka material tersebut digunakan untuk mendukung atau menyediakan kebutuhan produksi. Inventory bagi perusahaan adalah untuk mengantisipasi kebutuhan pelanggan.

Begitu juga dalam industri manufacturing, inventory digunakan untuk aktivasi perusahaan yang mana untuk memenuhi pelanggan yang kadang kala tidak dapat diprediksi sehingga kita harus menjaga stock inventory dalam kegiatan produksi. Hal yang tidak dapat diprediksi pun bukan saja terjadi atas pelanggan yang menginginkan barang dari perusahaan kita. inventory juga berperan sebagai buffer dalam hal supply dan demand. Sementara itu, inventory juga berperan sebagai buffer dalam hal supply dan demand, memenuhi customer demand (permintaan atau kebutuhan pelanggan), menyediakan komponen-komponen yang dibutuhkan untuk produksi" [4].

Adapun serangkaian pencatatan data inventory, sebagai berikut :[5]"

1. Unit organisasi/ departemen harus mencatat dan menghimpun data aset.

2. Harus mempersiapkan laporan mengenai pertanggung jawaban atas penguasaan dan pengelolaan aset organisasi/ negara.

3. Harus Menyiapkan dan menyediakan bahan acuan untuk pengawasan aset organisasi atau negara.

4. Menyediakan informasi mengenai aset organisasi / negara yang dikuasahi departemen sebagai bahan untuk perencanaan kebutuhan, pengadaan dan pengelolaan perlengkapan departemen.

5. Untuk menunjang perencanaan dan pelaksanaan tugas departemen maka pihak departemen harus menyediakan informasi tentang aset organisasi / negara"

Oleh karena itu, inventarisasi harus dikelola dengan sebaik mungkin melalui tahapan berikut ini, meliputi :

1. Membuat pembukuan penggudangan yang jelas dan mudah diperiksa

2. Membuat pembukuan mengenai mutasi barang (penerimaan dan permintaan barang)

3. Membuat pembukuan mengenai :
a) Buku Penerimaan Barang/Gudang
b) Buku Pengeluaran Barang/Gudang
c) Buku Kekayaan Gudang
d) Kartu Persediaan Barang

4. Untuk membuat pembukuan pada point 3 ini diperlukan karyawan khusus yang sesuai dengan bidangnya masingmasing

5. Barang yang masih disimpan di dalam gudang harus diberikan nilai/harga sesuai dengan faktur atau bukti-bukti lainnya.

\section{B. XAMPP}

"Suatu sistem operasi dengan menggunakan web server local memungkinkan sebuah web dinamis bisa diakses secara lokal, yang memiliki berbagai fasilitas seperti Windows, Linux, Mac, dan Solaris[6]. XAMPP merupakan singkatan dari : $X$ (Cross Platform) karena dapat bisa dijalankan di Windows, Linux, Mac, dan Solaris, A (Apache) merupakan web server nya, M (MySQL) merupakan Database Management System (DBMS), PP (PHP dan Perl) sebagai bahasa pemrograman yang didukungnya".

\section{C. $P H P$}

"PHP adalah sebuah bahasa pemrograman web berbasis server (server-side) yang mampu memparsing kode PHP dari kode web dengan ekstensi.php, sehingga menghasilkan tampilan website yang dinamis di sisi client (browser).[7] PHP adalah bahasa script yang sangat cocok untuk pengembangan web dan dapat dimasukkan ke dalam HTML"

\section{D. $M Y S Q L$}

"Database MYSQL merupakan database yang sangat kuat dan cukup stabil untuk digunakan sebagai media penyimpanan data sehingga database ini paling digemari di kalangan programmer web, dengan alasan bahwa program ini sebagai sebuah database server yang mampu untuk memanajemen database dengan baik, MySQL terhitung merupakan database yang paling digemari dan paling banyak digunakan dibanding database lainnya[8]".

\section{E. Unified Modeling Language (UML)}

"Unified Modeling Language (UML) adalah bahasa pemodelan yang memiliki standarisasi untuk pembangunan suatu perangkat lunak dengan menggunakan teknik pemrograman berorientasi objek". [9]

\section{F. Penelitian Terdahulu}

Perancangan Sistem Informasi Inventory Data Barang pada PT. Andalas Berlian Motors:

"Komputer telah menjadi alat bantu utama dalam tiap kegiatan manusia. Tidak hanya untuk aplikasi bisnis, namun juga dalam kegiatan sehari-hari dari setiap perusahaan. Hal ini menunjukkan bagaimana komputer telah menjadi bagian dari evolusi manusia terhadap teknologi. Penelitian yang dilakukan pada PT. Andalas Berlian Motors Bukittinggi, berorientasi pada pengolahan data Inventory dan penyajian informasi secara komputerisasi. Dalam artian sistem yang akan dirancangan mampu menyelesaikan permasalahan yang dihadapi mulai dari pengolahan data inventory yang masih dilakukan secara manual serta proses penyajian informasi yang tidak efisien dan akurat serta kurangnya efisiensi waktu. Untuk itu diperlukan pengoptimalan penggunaan komputer terhadap pemrosesan data dengan perancangan sebuah sistem informasi yang diaplikasikan kedalam bahasa pemrograman Java dan database MySQL agar dapat memecahkan permasalahan-permasalahan yang ada dengan mampu menjawab kebutuhan perusahaan" [9]. 
Penerapan Metode Sdlc Waterfall Dalam Sistem Informasi Inventory Barang Berbasis Desktop:

"Berdasarkan penelitian yang telah dilakukan pada perusahaan De Lapisa Cakes diperoleh bahwa suatu sistem yang diterapkan belum menggunakan teknologi komputerisasi dalam proses kegitannya sehari. Berdasarkan penelitian tersebut penulis mencoba membuat sebuah rancangan aplikasi guna menunjang aktivitas kegiatan perusahaan dengan menggunakan bahasa pemrograman VB.NET. Untuk metode pengembangan software dilakukan dengan menggunakan metode SDLC Waterfall. Dengan penggunaan aplikasi ini diharapkan dapat mempermudah dan mempercapat pengaksesan data barang, serta mempermudah pembuatan laporan barang masuk dan keluar dan menghasilkan laporan yang jauh lebih baik. Selain itu dapat membantu mengontrol kapasitas gudang penyimpanan stok. Hasil pengamatan dari penelitian yang telah dilakukan pada perusahaan De Lapisa Cakes, diketahui bahwa sistem pencatatan persediaan barang belum terkomputerisasi. Media kertas merupakan alat yang digunakan untuk mencatat setiap transaksi pada perusahaan tersebut. Akibatnya laporan yang dihasilkan sering terjadi kesalahan karena hilang dan rusaknya bukti transaksi. Berdasarkan permasalahan yang terjadi dibutuhkannya sebuah rancangan system yang terkomputer agar dapat mengurangi humans error pada proses pembuatan laporan maupun proses pencatatan transaksi. Peneliti mengembangkan sebuah rancangan perangkat lunak yang dapat mengatasi permasalahan yang terjadi pada perusahaan De Lapisa Cakes. Rancangan yang dibuat menggunakan bahasa pemrogramman Visual Studio 2010 dan menerapkan metode SDLC Waterfall sebagai metode pengembangan perangkat lunak. Perangkat lunak ini diharapkan dapat mempermudah proses pencatatan transaksi, mengurangi kemungkinan terjadinya humans error, menghasilkan laporan yang lebih baik dengan waktu yang singkat, dan mempermudah management dalam mengambil keputusan dengan adanya laporan-laporan pendukung" [10].

\section{METODOLOGI PENELITIAN}

Metode waterfall merupakan metode pengembangan sistem yang pakai dalam penelitian ini [11]. Model sekuensial linier (sequential linear) merupakan nama lain dari metode ini sering atau biasa juga disebut alur hidup klasik (classiclife cycle). Tahap analisis, desain, pengodean, pengujian, dan pemeliharaan merupakan tahap-tahap yang ada pada metode ini.

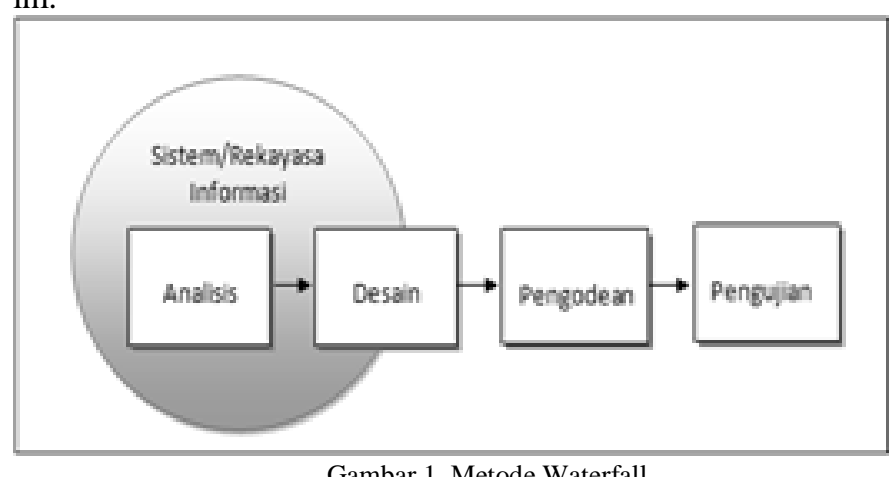

Gambar 1. Metode Waterfall

\section{A. Analisis}

Pada proses analisis ini adapun yang dibutuhkan adalah data-data mengenai inventory yang ada pada setiap bagian pada PT. PLN (Persero) yaitu dengan cara observasi, wawancara dan juga studi literatur yang didapat dari beberapa buku dan literatur

\section{B. Desain}

Berdasarkan data-data yang telah dianalisis, langkah selanjutnya yaitu mendisain perangkat lunaknya, mulai dari desain UML, seperti usecase diagram, aktivity diagram, class diagam lalu desain database dan desain interface atau antar muka dari program yang akan dibuat.

\section{Pengkodean}

Setelah tahap desain selesai lalu ditranslasikan ke dalam program perangkat lunak. program komputer yang telah sesuai dengan desain yang telah dibuat merupakan hasil dari tahap pengkodean ini

\section{Pengujian}

Untuk meminimalisir kesalahan (error) pada program yang telah dibuat maka tahap pengujian ini di perlukan. Pengujian disini dilakukan setelah program selesai di buat untuk memastikan bahwa semua bagian sudah diuji dan memastikan keluaran yang dihasilkan sesuai dengan yang diinginkan.

\section{E. Pemeliharaan (Maintenance)}

Tahap pemeliharaan biasanya digunakan jika ada perubahan atau jika terjadi kesalahan yang muncul akibat tidak terdeteksinya error pada saat pegujian. Tahap pendukung ini hanya digunakan untuk perubahan perangkat lunak yang sudah ada dan tidak untuk membuat perangkat lunak baru.

\section{HASIL DAN PEMBAHASAN}

Penelitian ini menghasilkan sistem informasi inventaris di PT.PLN (Persero) di Rayon Rivai WS2JB Area Palembang.

\section{A. Analisis}

Tahap awal dalam penelitian ini adalah tahapan analisis. Analisis sistem yang berjalan yang sering di alami PT. PLN (persero) di rayon rivai WS2JB Palembang yaitu terjadinya kesulitan dalam penyajian laporan data barang-barang inventaris, di karnakan penginputan dan pemrosesan dilakukan dalam waktu yang lama, dan sering terjadi kesalahan dan duplikasi data dalam penginputannya. Untuk itulah dibutuhkan sebuah sistem informasi inventaris di PT.PLN (Persero) di Rayon Rivai WS2JB Area Palembang. Untuk membangun sistem tersebut perlu adanya analisis kebutuhan sistem yang dibutuhkan antara lain spesifikasi hardware dan software yang dapat dilihat pada tabel 1 . 


\begin{tabular}{|l|l|l|}
\hline \hline \multicolumn{2}{|c|}{ Tabel 1 1. Software dan Hardware Pendukung } \\
\hline Kebutuhan Sistem & \multicolumn{1}{c|}{ Spesifikasi } \\
\hline Hardware/ PC & CPU & Intel Atom atau lebih \\
& RAM & 2 GB atau lebih \\
& HDD & 160GB atau lebih \\
& Network & 10/100 Ethernet, 802.11bgn \\
& & wireless \\
& Port & USB2.0, USB3.0 \\
\hline Software & OS & Windows 7 atau lebih \\
& Program & PHP, MySQL, Dreamweaver, \\
& & XAMPP, Browser \\
\hline
\end{tabular}

\section{B. Desain}

Tahapan selanjutnya adalah tahapan desain. Desain yang dibuat dalam penelitian ini adalah desain usecase dan desain activitydiagram dan desain classdiagram dari sistem yang akan dibuat.

\section{1) Usecase Diagram}

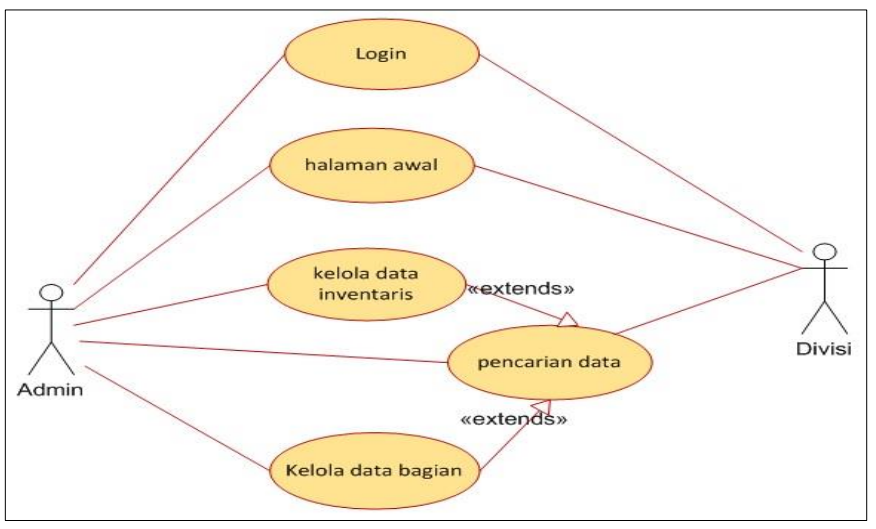

Gambar 2. UsecaseDiagram Sistem

Pada gambar 2, aktor admin dan aktor divisi/bagian memiliki askes yang hampir sama terhadap sistem, tetapi seorang admin dapat mengelola data inventaris dan mengelola data bagian/divisi, sedangkan aktor divisi hanya melihat data berdasarkan pencarian data yang bergantung dari pengelolaan data inventaris dan data bagian.

\section{2) Activity Diagram}

Langkah awal yang dilakukan admin adalah login ke dalam sistem, kemudian memilih menu, menginputkan data bagian dan data inventaris serta mencari data inventaris. Activity diagram admin dapat dilihat pada gambar 3 .

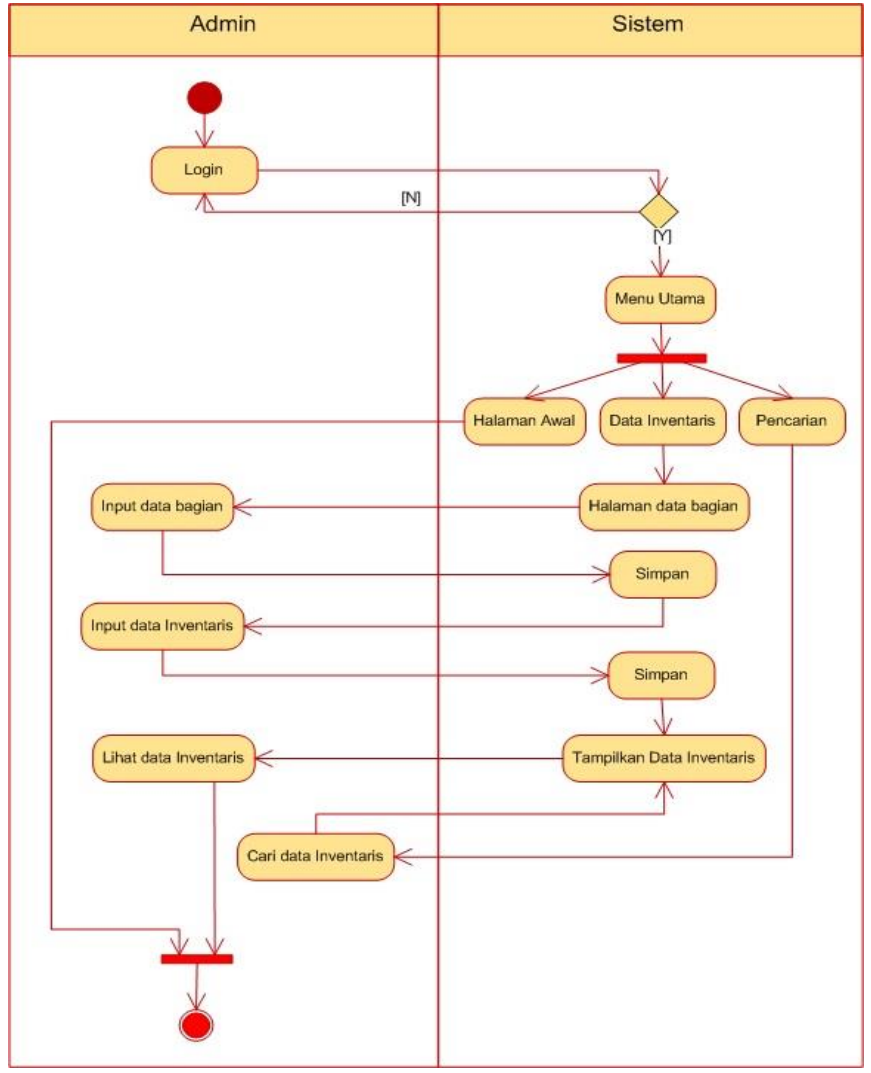

Gambar 3. Activity Diagram Admin

\section{3) Class Diagram}

Class diagram di penelitian ini terdiri dari 5 buah class, terdiri dari class admin, class halamanutama, class inventaris, class bagian, class pencarian, masing-masing terdiri dari atribut dan operasi, seperti pada gambar 4.

\begin{tabular}{|c|c|c|}
\hline Admin & \multirow{5}{*}{\begin{tabular}{l}
\multicolumn{1}{c}{ Inventaris } \\
-nm_brg : string \\
-merk : string \\
-jumlah : int \\
-satuan : string \\
-ket : string \\
-kategori : string \\
-nm_bagian : string \\
-tahun : int
\end{tabular}} & bagian \\
\hline \multirow{2}{*}{$\begin{array}{l}\text {-id_admin : int } \\
\text {-nm_admin : string } \\
\text {-pwd : string }\end{array}$} & & -nm_bagian : string \\
\hline & & $\begin{array}{l}\text { +save(): void() } \\
\text { +update(): void() }\end{array}$ \\
\hline $\begin{array}{l}\text { +save(): void() } \\
\text { +update(); void() } \\
\text { +delete(): void() }\end{array}$ & & \\
\hline & & \\
\hline HalamanUtama & $\begin{array}{l}\text { +save(); void() } \\
\text { +update(): void() }\end{array}$ & \\
\hline +onCreate(): void() & & \\
\hline
\end{tabular}

\section{Pengkodean}

Setelah desain selesai dibuat, langkah selanjutnya adalah pengkodean yaitu proses pembangunan sistem menggunakan beberapa perangkat lunak dan terdiri dari beberapa tampilan sistem. 


\section{1) Мепи Login}

Menu login digunakan untuk masuk ke dalam sistem Informasi Inventaris PT.PLN (persero) di Rayon Rivai WS2JB Area Palembang seperti pada gambar 5.

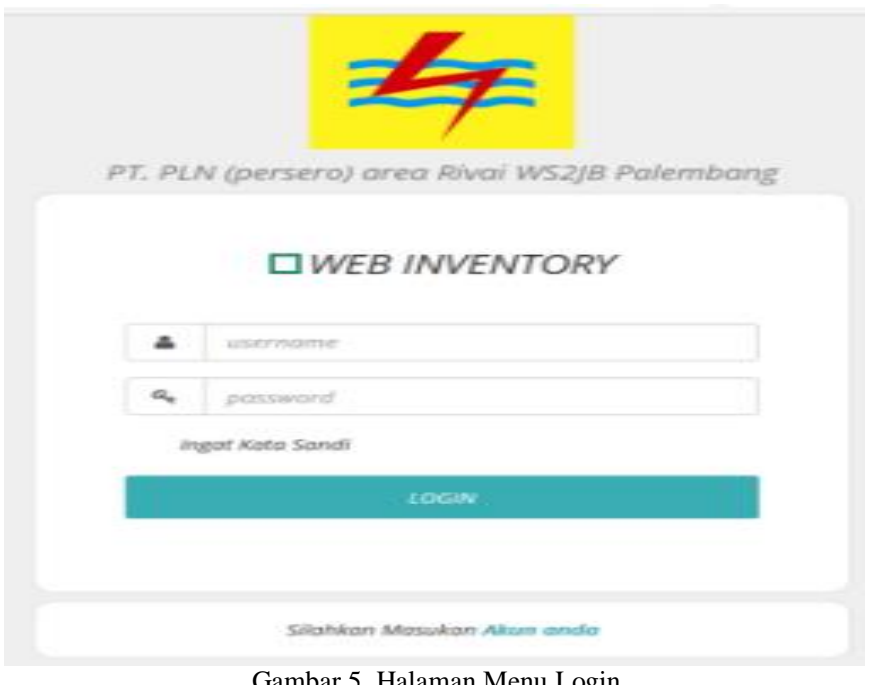

Gambar 5. Halaman Menu Login

2) Menu Data Bagian atau divisi

Halaman data bagian merupakan halaman untuk melihat bagian-bagian ayau divisi yang ada di PT.PLN (persero) di Rayon Rivai WS2JB Area Palembang yang terdiri dari 15 divisi dan masing-masing memiliki barang inventaris sendiri.

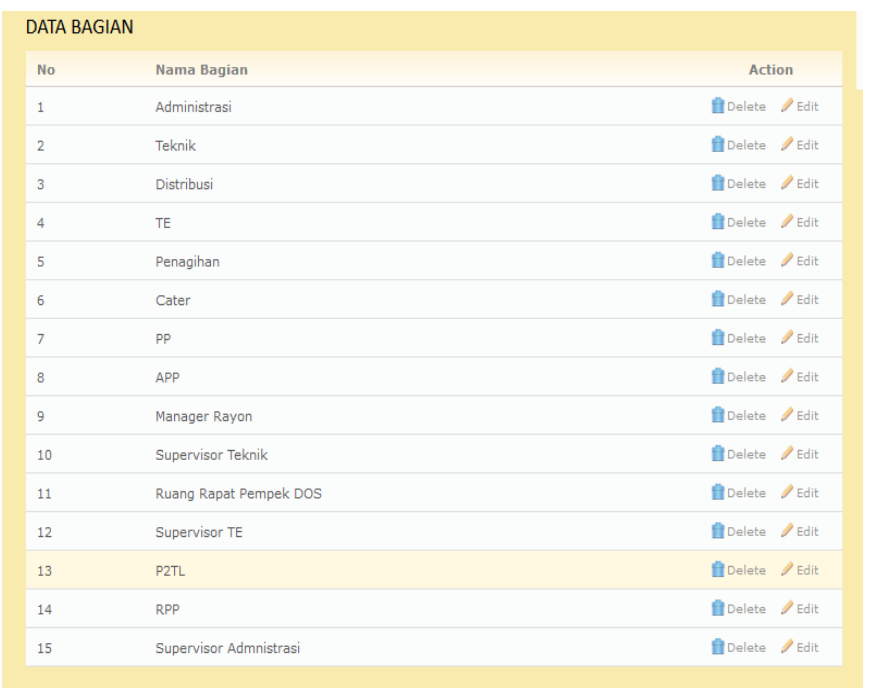

Gambar 6. Menu Data Bagian atau Divisi

\section{3) Menu Laporan Inventaris Divisi Administrasi}

Menu ini berisi tentang seluruh barang inventaris yang ada pada divisi Administrasi. Pada divisi ini terdapat 23 item barang tidak habis pakai dan semuanya dalam kondisi yang baik

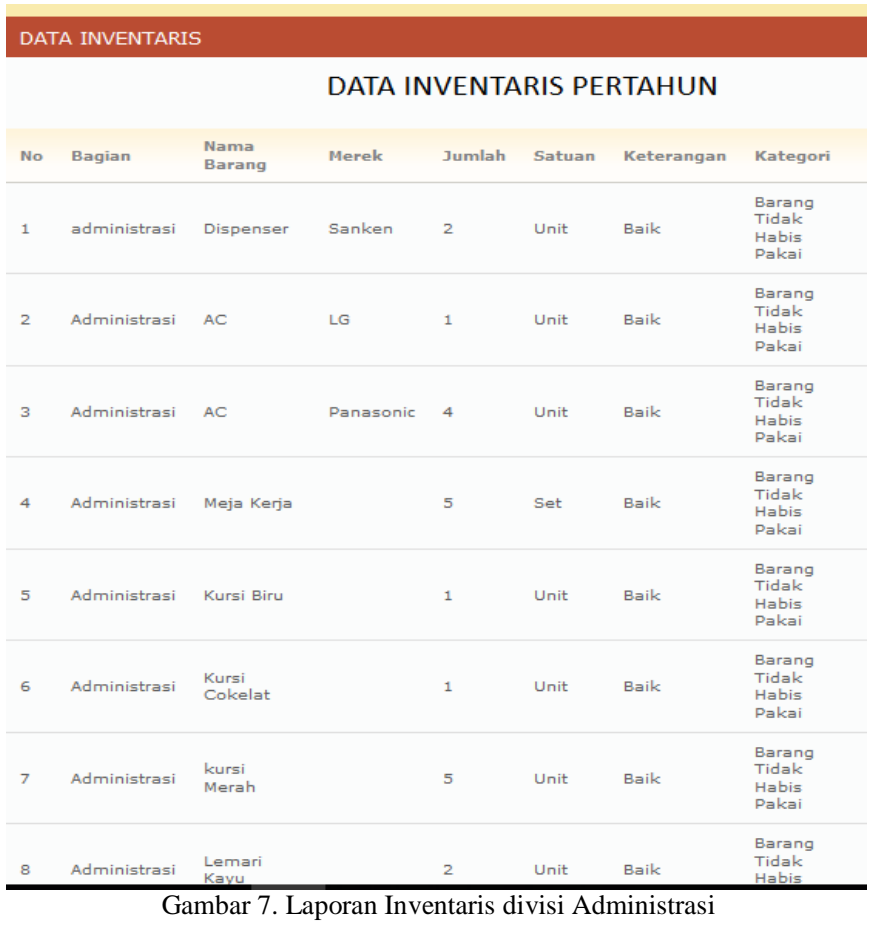

4) Menu Laporan Inventaris divisi Teknik

Pada menu ini berisi data barang inventaris khususnya pada divisi Teknik yang terdiri dari 12 barang yang tidak habis pakai dan dalam kondisi yang baik.

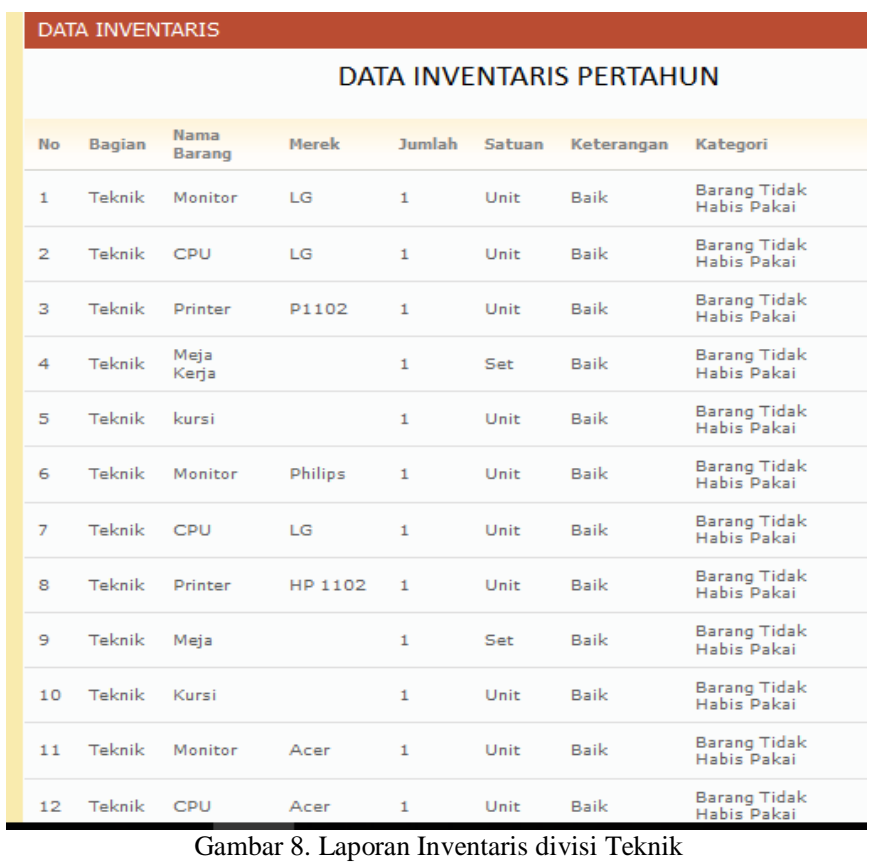

5) Menu Laporan Inventaris divisi Pelayanan Pelanggan

Pada divisi ini barang inventaris yang tergolong kategori barang tidak habis pakai berjumlah 6 (enam) unit dan dalam kondisi yang baik. 


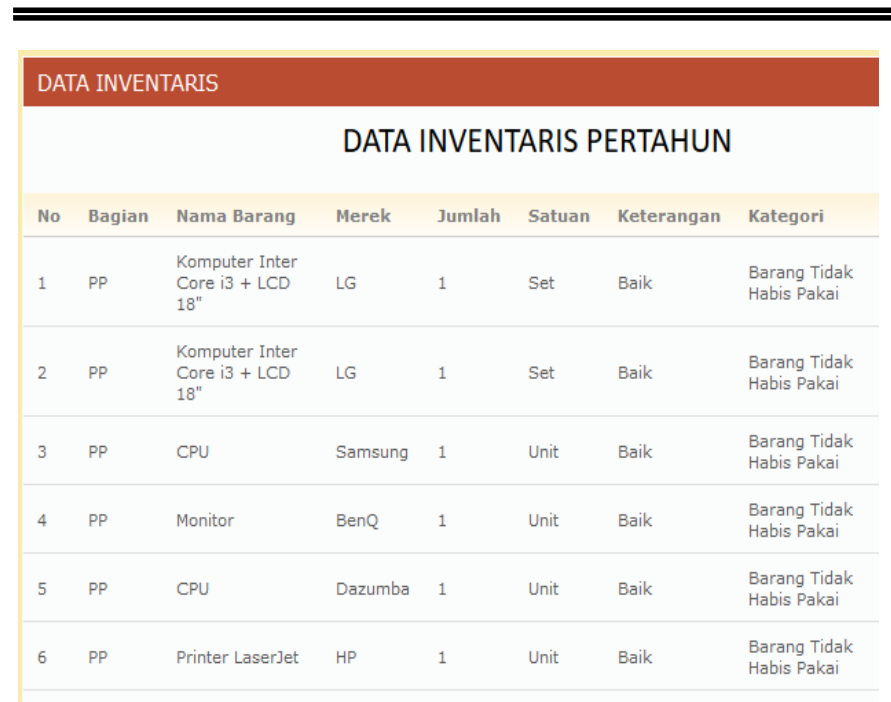

Gambar 9. Laporan Inventaris Divisi Pelayanan Pelanggan

6) Menu Laporan Inventaris divisi Transaksi Energi ( TE )

Menu ini merupakan halaman yang menampilkan seluruh data inventaris yang telah diinpukan ke dalam sistem. Data inventaris yang ditampilkan ini merupakan laporan dari data inventaris yang ada pada divisi TE. Pada divisi ini terdapat 7 (tujuh) item barang yang tidak habis pakai dimana jumlah masing-masing barang tersebut terdiri dari 1 unit barang dan dalam kondisi yang baik

\section{DATA INVENTARIS}

\section{DATA INVENTARIS PERTAHUN}

\begin{tabular}{|c|c|c|c|c|c|c|c|}
\hline No & Bagian & $\begin{array}{l}\text { Nama } \\
\text { Barang }\end{array}$ & Merek & Jumlah & Satuan & Keterangan & Kategori \\
\hline 1 & TE & $\mathrm{CPU}$ & Sim- $X$ & 1 & Unit & Baik & $\begin{array}{l}\text { Barang Tidak } \\
\text { Habis Pakai }\end{array}$ \\
\hline 2 & TE & Monitor & Samsung & 1 & Unit & Baik & $\begin{array}{l}\text { Barang Tidak } \\
\text { Habis Pakai }\end{array}$ \\
\hline 3 & TE & $\mathrm{CPU}$ & Samsung & 1 & Unit & Baik & $\begin{array}{l}\text { Barang Tidak } \\
\text { Habis Pakai }\end{array}$ \\
\hline 4 & TE & Monitor & Samsung & 1 & Unit & Baik & $\begin{array}{l}\text { Barang Tidak } \\
\text { Habis Pakai }\end{array}$ \\
\hline 5 & TE & $\begin{array}{l}\text { Printer } \\
\text { Laser Jet }\end{array}$ & HP 1102 & 1 & Unit & Baik & $\begin{array}{l}\text { Barang Tidak } \\
\text { Habis Pakai }\end{array}$ \\
\hline 6 & TE & $\mathrm{CPU}$ & Basic & 1 & Unit & Baik & $\begin{array}{l}\text { Barang Tidak } \\
\text { Habis Pakai }\end{array}$ \\
\hline 7 & TE & $\begin{array}{l}\text { Printer } \\
\text { Laser Jet }\end{array}$ & HP 1006 & 1 & Unit & Baik & $\begin{array}{l}\text { Barang Tidak } \\
\text { Habis Pakai }\end{array}$ \\
\hline
\end{tabular}

Gambar 10. Laporan Inventaris divisi TE

\section{7) Menu Laporan Inventaris divisi Penagihan}

Pada divisi ini barang inventaris yang tergolong kategori barang tidak habis pakai berjumlah 4 (empat) unit dan dalam kondisi yang baik.

\section{DATA INVENTARIS}

\section{DATA INVENTARIS PERTAHUN}

\begin{tabular}{|c|c|c|c|c|c|c|c|}
\hline No & Bagian & Nama Barang & Merek & Jumlah & Satuan & Keterangan & Kategori \\
\hline 1 & Penagihan & $\begin{array}{l}\text { Komputer Inter } \\
\text { Core i3 + LCD } \\
18^{\prime \prime}\end{array}$ & LG & 1 & Set & Baik & $\begin{array}{l}\text { Barang Tidak } \\
\text { Habis Pakai }\end{array}$ \\
\hline 2 & Penagihan & CPU & Basic & 1 & Unit & Baik & $\begin{array}{l}\text { Barang Tidak } \\
\text { Habis Pakai }\end{array}$ \\
\hline 3 & Penagihan & Monitor & LG & 1 & Unit & Baik & $\begin{array}{l}\text { Barang Tidak } \\
\text { Habis Pakai }\end{array}$ \\
\hline 4 & Penagihan & $\begin{array}{l}\text { Printer Laser]et } \\
1005\end{array}$ & Epson & 1 & Unit & Baik & $\begin{array}{l}\text { Barang Tidak } \\
\text { Habis Pakai }\end{array}$ \\
\hline
\end{tabular}

Gambar 11. Laporan Inventaris divisi Penagihan

\section{Pengujian}

Teknik pengujian yang digunakan dalam penelitian ini adalah pengujian blackbox. Pengujian blackbox menitikberatkan pada fungsi sistem. Teknik ini digunakan untuk mengetahui apakah perangkat lunak berfungsi dengan benar. Hasil pengujian sistem menggunakan teknik blackbox dapat dilihat pada tabel 2 .

Tabel 2. Hasil Pengujian Blackbox

\begin{tabular}{|l|l|l|l|l|}
\hline No & Pengujian & $\begin{array}{l}\text { Hasil yang } \\
\text { diharapkan }\end{array}$ & $\begin{array}{l}\text { Hasil } \\
\text { pengujian }\end{array}$ & Kesimpulan \\
\hline 1 & Login & $\begin{array}{l}\text { Menampilkan } \\
\text { menu utama }\end{array}$ & $\begin{array}{l}\text { Sistem } \\
\text { menampilk } \\
\text { an menu } \\
\text { utama }\end{array}$ & Diterima \\
\hline 2 & $\begin{array}{l}\text { Simpan } \\
\text { data } \\
\text { inventaris }\end{array}$ & $\begin{array}{l}\text { Sistem } \\
\text { menampilkan } \\
\text { form data } \\
\text { inventaris }\end{array}$ & $\begin{array}{l}\text { Sistem } \\
\text { menampilk } \\
\text { an form } \\
\text { data diterima } \\
\text { inventaris }\end{array}$ & \\
\hline 3 & $\begin{array}{l}\text { Edit data } \\
\text { inventaris }\end{array}$ & $\begin{array}{l}\text { Sistem } \\
\text { menampilkan } \\
\text { form data } \\
\text { inventaris }\end{array}$ & $\begin{array}{l}\text { Sistem } \\
\text { menampilk } \\
\text { an form } \\
\text { data diterima } \\
\text { inventaris }\end{array}$ & \\
\hline 4 & $\begin{array}{l}\text { Simpan } \\
\text { data bagian }\end{array}$ & $\begin{array}{l}\text { Sistem } \\
\text { menampilkan } \\
\text { form data } \\
\text { bagian }\end{array}$ & $\begin{array}{l}\text { Sistem } \\
\text { menampilk } \\
\text { an form } \\
\text { data bagian }\end{array}$ & diterima \\
\hline 5 & $\begin{array}{l}\text { Edit data } \\
\text { bagian }\end{array}$ & $\begin{array}{l}\text { Sistem } \\
\text { menampilkan } \\
\text { form data } \\
\text { bagian }\end{array}$ & $\begin{array}{l}\text { Sistem } \\
\text { menampilk } \\
\text { an form } \\
\text { data bagian }\end{array}$ & diterima \\
\hline 6 & $\begin{array}{l}\text { Pencarian } \\
\text { data }\end{array}$ & $\begin{array}{l}\text { Sistem } \\
\text { menampilkan } \\
\text { data inventaris }\end{array}$ & $\begin{array}{l}\text { Sistem } \\
\text { menampilk } \\
\text { an data } \\
\text { inventaris } \\
\text { yang dicari }\end{array}$ & diterima \\
\hline & & & \\
\hline
\end{tabular}

\section{KESIMPULAN}

Penelitian ini menghasilkan sebuah sistem informasi untuk menginventariskan barang di PT. PLN (persero) di rayon rivai WS2JB palembang. Dengan sistem yang terkomputerisasi akan dapat memudahkan pengguna dalam mengelola data 
inventaris sehingga membuat pekerjaan menjadi lebih efektif dan efisien dimana sistem ini dapat melakukan proses pencarian barang-barang inventaris serta dapat membuat laporan data barang inventaris secara cepat dan akurat sehingga tidak akan terjadi duplikasi data.

\section{DAFTAR PUSTAKA}

[1] Huda, Nurul. 2019. "Analisis Situs WEB Kinerja PT. PLN (Persero) Menggunakan Metode PIECES". Jurnal Sistemasi Vol. 8 No. 1, Januari 2019. hal. 78-89

[2] Rakhel, Yuniati dkk. 2016. "Perancangan Sistem Informasi Inventaris berbasis mobile (Studi Kasus: STMIK Provisi Semarang)". Jurnal KOMPUTAKI Vol. 1 No. 1 Februari 2016, hal. 132-145.

[3] Sudarsono,Nono \& Sukardi. 2015. "Sistem Informasi Inventory Berbasis Web di PT. Autotech Indonesia". Jurnal Eksplora Informatika Vol. 5 No. 1 September 2015, hal. 73-84

[4] Nugraha Wahyu, dkk. 2018. "Penerapan Metode SDLC Waterfall dalam Sistem Informasi Inventory Barang Berbasis Desktop". Jurnal Sistem Informasi Musi Rawas (JUSIM). Vo. 03 No. 01, Juni 2018, hal. 23-29

[5] http://www.google.com/"jurnal perencanaan inventarisasi peralatan kantor dengan aplikasi microsoft access". (10 Oktober 2018).

[6] Huda, Nurul. 2019. "Aplikasi Bahasa Isyarat Pengenalan Huruf Hijaiyah Bagi Penyandang Disabilitas TunaRunggu". Jurnal Sisfokom STMIK Atma Luhur Vol. 8 No. 1, 26 Maret 2019, ISSN: 2301-7988 E-ISSN: 2581- 0588. hal. 1-6.

[7] Syukri Ali., Arisandy Ambarita. 2016. "Sistem Informasi Data Barang Inventaris Berbasis Web Pada Kejaksaan Negeri Ternate". Jurnal Indonesian Journal on Information System (IJIS) Vol. 1 No. 1 April 2016, hal.31-38

[8] Rosa, A.S. \& Shalahuddin, M. 2014. "Modul Pembelajaran Rekayasa Perangkat Lunak". Modula: Bandung

[9] Veza, Okta \& Ropianto,M. 2017. "Perancangan Sistem Informasi Inventory Data Barang pada PT. Andalas Berlian Motors". Jurnal Teknik Ibnu Sina (JT-IBSI) Vol. 2 No. 2 Oktober 2017, ISSN : 25412647.

[10] Nugraha, Wahyu. Syarif, Muhamad. Dharmawan, WS. 2018. "Penerapan Metode SDLC Waterfall Dalam Sistem Informasi Inventori Barang Berbasis Desktop". Jurnal Sistem Informasi Musi Rawas ( JUSIM) Vol. 03 No. 01 Juni 2018.

[11] Huda, Nurul. 2017. "Sistem Informasi Wisata Sumatera Selatan Berbasis Mobile". Jurnal Teknik Informatika Politeknik Sekayu (TIPS) Volume VII, No.2, Juli - Desember 2017, ISSN-P 2407-2192, hal. 5156. 